\title{
Developing English Reading Materials For Second Year Students Of Islamic Education In IAIH NW Anjani Especially (Islamic Education For B Class In 2018-2019)
}

\author{
Muh. Bisyrulhafy \\ Iaih NW Anjani
}

\begin{abstract}
Developing English Reading Materials for the students of IAIH NW Anjani. It modified Latief model (2009); the lecturer developed material based on data analysis taken from preliminary data. The material was validated and tried-out to B class of Islamic education in second semester 2018-2019. The result showed that this study and the product have successfully answered the students' needs in reading skill. Therefore, the product could be used for Islamic education especially for $2^{\text {rd }}$ semester.
\end{abstract}

Key words: Reading material

\section{INTRODUCTION}

Among other language skill, reading is the most important skill for academic purpose in second language acquisition. A lot of foreign language teaching often emphasize on reading activities. Therefore, various pedagogical purposes help reading to receive this special focus. It becomes more important in today's world in which the development in every life aspect occurs very quickly (Burns et al., 1996:5 6). Loucky (1996:1) states that reading as one of the four language skills is a complex and multi-faceted activity in English as a Foreign Language (EFL) context. Therefore, it needs to be developed in EFL teaching as stated by Pearson \& Fielding (1991:816) that spending time on reading in class is important since readers-the studentscan get a lot of advantage from the time to apply reading skill and strategies and to acquire new knowledge.

Reading requires word recognition, comprehension and fluency (Leipzig, 2001). Comprehension is affected by all aspects of the reading process so that word recognition strategy is one of the aspects of reading process (Burns et al., 1996:7). Hence, to understand all types of information in the whole texts, it requires either reading activity or ability to understand the content. Without the ability to understand it, the students are not able to absorb or comprehend a lot of information quickly, accurately and easily.
This research is conducted in $2^{\text {rd }}$ semester of Islamic education of IAIHNW Anjani. The students of that level get hard $t$ to understand descriptive text that talk about Islam. Even, some students do not like to read English reading material because they think that the language used in the available reading materials are too difficult for them. Based on this condition, the teachers have to find ways to solve problem.

Reading skill plays an important role in English learning process, especially when students have to deal with final examination which includes reading and writing skills. Reading is an ability to draw meaning from the printed page and interpret this information appropriately. So, the important aspects to acquire by the students Of Islamic Education are vocabulary and grammar since they are still much mistakes and 1 lack of vocabulary or it is called as lower level reading process (Grabe, W. \& Fredricka L. Stoller, 2002).

To have good reading skill, students need to receive ample reading input or many reading materials. According to Krashen (2003), the learner need to be exposed a large amount of comprehensible input in their new language in order to acquire the language. These reading input are not only in the intensive reading activity but also in the extensive reading activity where the student can read freely inside or outside the classroom. Harmer (2007:283) assert that to 
get optimum benefit from reading, student need to be involved in both intensive and extensive reading. It is because of the teacher develops students' reading materials, logically the materials selected for the module should be able to trigger students' motivation to read.

The purpose of this study is producing a book about Reading Materials to help students for reading skill especially to Islamic education in $2^{\text {rd }}$ semester. As it stated in Cunningsworth (1995) that reading material especially graded book expected to answer the disadvantage of course book that is improving varieties in teaching procedures, responding individual student needs and problems, and also improve the creativity in teaching technique and language

The final product is The final product of this development is in the form of book entitled "let's read" islamic reading material for Islamic education". The cover was designed in green with attachment of mosque. The second part is the title of supplementary that followed by the name of writer, lay-out, illustrate, cover design, edition and year. The third part is preface; it describes the reason why reading material is developed and the aim of providing reading text. Next is to the lecturer, it introduces the content of product. It is followed by list of content and continued with the map of content. The next part is the materials staring with Unit 1 till unit 3, in each unit provides a meaningful picture and the objectives of instructional activities. The last part is answer key and lecturer's guide.

The result of the study would be useful for the English lecturer in IAIH NW Anjani to overcome the problem reading and student's difficulty in reading skill. This study can also become one of the guideline for lecturer and further researcher who will develop other materials. The result of this reading material is also expected to complement the previous and available the materials of reading in course book.

The product is developed on the basis of the assumption that the supplementary materials are suitable for the students' need and interest and also the material can improve the students' reading ability. It is based on
Crawley \& Mountain (1995) suggests that material adjustment can be made in a number of ways; one of them is supplementary reading. It is very essential to use reading in the content areas. Supplementary reading should be compilation of sources such as pictures books and trade books (Roe, Stood, and Burns, 1995). They state that reading materials can developed critical thinking skills, to make a connection between reading and writing, and to develop vocabulary.

The supplementary materials focus on the topics about Islamic; All Praise is Due to God, Why do pray, The Mosque In Islam , The Qur'an , Hajj , Zakat., The Creation of Adam. Based on the result of applying the topics to students, they are familiar bout that topics. The students knew the meaning of the topics but they could not translate the text well. Also, students only have less reading English text about Islamic. So, those are expected that he students motivated to read much more Islamic theme by focusing the material development on the topics.

The definition of reading material is the material that supports the main course book usage. The contents are only additional materials, which support and give reinforcement for the proposed and selected materials in the course book. Reading text materials are interactive activity that followed by exercises; matching word, reading text question, playing puzzle. It is also doing practice for English conversation section..

\section{METHOD}

The researcher decided to adapt Latif (2009) model and procedures of

development as displayed in Figure 1.1.

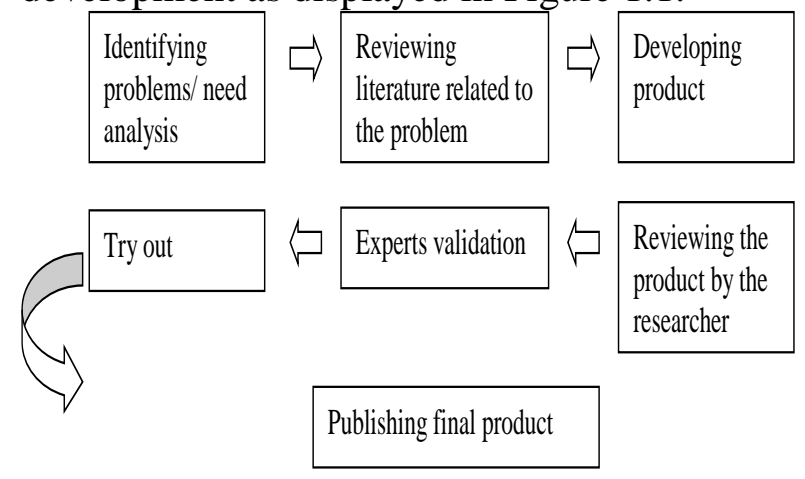


In this study, need analysis is the first step of the process of the development. It was conducted to obtain as much information as possible from foundation, principle, lecturer and the students of $2^{\text {rd }}$ semester of Islamic education, the problems they have, and their hope related to reading materials are needed for developing appropriate reading materials relate to Islam.

To gather the data in need analysis, the instrument used were the interview guide and the questionnaire. The interview guide was used to interview the students of Islamic education in second semester. The researcher also had interview and distributed questionnaire to the students.

The information got from the questionnaire are related to the students' reading habit in English, existence of reading materials in the campus, the content of reading materials they like and dislike, the need for Islamic reading materials, and their hope about the criteria of the reading materials for the students of Islamic education in second semester

After knowing much information about the problem the student have, the hope and their expectation and developing materials, the next step is reviewing some related literature. The focus in this reviewing literature is finding some criteria from many experts about good supplementary reading materials. Some of them are that they should (1) be interesting and understandable that are at I minus level or below the students linguistics ability (Bamford, 1998), (2) use simplified text within controlled vocabulary that what nation (2002) calls 'grade graders', (3) help the students gain pleasure from reading, introduce new vocabulary and grammatical feature incidentally (Nation, 2002), (4) suitable with the need interest of the students will find interesting, and the teaching goals (Nutal, 1996) cited in Brown 2007: 374), (5) easy that the students does not need to open dictionary (Ono et. Al, 2004), (6) culturally appropriate and suitable with the value the students have (http://eltresourceful.com).
The next procedure of this study is developing materials. The development of the materials will be based on the information the researcher got from the need analysis. The materials wanted to be developed in this study are reading materials for extensive reading activity for the students of Islamic education. The reading materials should be easy to understand, attractive, interesting, and talking about Islam.

There will be some editing and simplifying process for the text that uses difficult words. There will also a little reading comprehension activities such as: true false and matching the picture and sentences in this product of development.

After the product is developed and before it is validated by the experts, the researcher read, check and recheck again whether there still inappropriate materials in term of the language (vocabulary and misspelling), the content, the topic, etc.

After that, Experts are selected to improve the quality of the product. So anybody whose expertise is needed to improve the quality of product can be selected as the experts for the validation (Latief, 2009). The experts must be the ones who are experience in the era. In the expert validation of this study, the researcher will include two experts. The experts validate the language are: English lecturer in other department and the lecturer of English (Nahdlatul Wathan University).

The next step is try-out. The try-out is intended to get feedback from the field subject. The try-out is done to collect the data about the applicability of the materials in term of level of difficulty, the usefulness, and the effectiveness. It is also used to point the area of inappropriateness needed to be revised. The Try-out in this study is conducted by giving the students the supplementary reading materials to be read and the researcher as them to give comments and suggestions. The subject of try out will be the students of Islamic education especially on B class.

After being validated by the experts and being tried out to students, the revision of the developed material is done. The revision is 
based on the evaluation, the comments, and the suggestion from the experts and the students as well. There will be at least twice revision. The first product revision is done after having experts' validation. After having try-out, there will be second revision and improvement of the product that is not suitable with the students or not friendly users to be better final product.

The last step of the development study is publishing product. The product will be printed (by publisher) and published in a lot of copies to fulfill the students' need.

\section{RESULT OF DEVELOPMENT}

The results of the try-out consist of the data from the first expert (E1) is an English teacher and the second expert (E2) is lecturer (Islamic university of Malang). The results of the validation were explicated as follows;

\section{The Good Points}

The first was design and layout. E1 and E2 are graded as "good" according to four criteria; (1) the cover is attractive to the students, (2) The layout is good and attractive to the students, (3) The typing is clear, neat and regular, (4) The use of letter is clear, appropriate, consistent, and readable.

The second was about topic. It was remarked "good" by E1 and E2 in three sub components; (1) the topics are interesting, (2) the topics are various, (3) the topics are ordered appropriately.

The third was instructional objective. According to both E1 and E2 this aspect was scored "good" follows some criterias: (1) The instructional objectives are clear, (2) The instructional objects are stated appropriately, (3) The instructional objectives are ordered appropriately.

The fourth was text. Both the expert 1 and expert 2 agreed to say "good" for the points: (1) the texts can develop the reading skill, (2) the text can be exploited into communicative task.

The fifth was the content. E1 and E2 are graded "good" based on criteria: (1) The content is clear, (2) The content is suitable to the objective of teaching and culture, (3) The content can be understood by the students
The sixth was task. E1 and E2 claimed that the tasks are appropriate to the given context and the task can be done by the students. So, both of them are graded as "good".

The seventh was activities. Between expert 1 and expert 2, they had same perception to say "good". It is according to three sub-points: (1) the activities are appropriate to the given context, (2) the number of activities in each chapter is sufficient (3) the activities can interestingly trigger the students' motivation.

The eighth was Language. Based on the expert 1 and expert 2, they agreed to grade "good" for sub-point; the language is clear and easy to understand.

Besides the good points described above, there were some adequate points from expert 1 and expert 2 grades. Those describe as follow:

\section{The adequate point}

The first was related to design and layout. E1 and E2 are graded as "adequate" according to the illustration are interesting. The second was organization of the materials. It was remarked "adequate" by E1 and E2 relate to three criteria; (1) The material are organized attractively, (2) The organization of materials in the form of units and sections are appropriate, (3) The materials are organized in logically order task. The third was text. According to both E1 and E2 this aspect was graded as "adequate" because of The number of texts in each chapter is sufficient. The fourth was vocabulary. Both of the experts agreed to say that the selection of vocabulary is appropriate for the target learners and the chapters cover sufficient activities related to the vocabulary use. The fifth was task. E1 and E2 are graded "adequate" based on criteria; The tasks are simple and clear, The tasks can integrate knowledge by the students about the topics and the language they learn. The sixth was activities. E1 and E2 claimed that the activities integrate knowledge and the target language. So both of them are graded as "adequate". The seventh was Coverage of materials; both experts said The materials are relevant to the students need and interest and 
the materials are suitable with the students level. The eighth was Language. Both experts agreed to grade "adequate" in line with The language is suitable to the level of students.

From what the experts had already been determined, the product is categorized valid. Nevertheless, the product still needs some revision to come to better materials before the product is tried-out.

\section{FINDING AND DISCUSION}

The appropriate topics which had been developed for Supplementary Reading Materials for the students of Islamic education based on students' needs that involve the Islamic topic like All Praise is Due to God, Why do pray, The Mosque In Islam , The Qur'an , Hajj , Zakat., The Creation of Adam.This is also supported by (1998) who stated that a good reading material should be contextualized to topics and themes that provide meaningful, purposeful uses for the target language.

The product of this study has already fulfilled all requirements of what is so-called a good reading material since it was constructed by considering the criteria of a good material from Tomlinson (1998)). A contextual material is a must, where in activities. It means that all materials should be interested topics and themes that provide meaningful, purposeful uses for the target language. Good materials should be attractive. Moreover, all materials presented in this product could stimulate interactions and be generative in term of language meaning. Then students can do interaction and generate learning language through the activities. Also, this product could encourage the students to develop learning skills and strategies which are also a part of the development of the product where all material could motivated students to learn something from the reading material where they will know about the form of the text and also the function of the text through reading.

The integration of language use was also considered in the production of this product so it will allow student to integrate the language skills and improve their language quality. In term of authenticity, all reading materials were taken from a Islamic sources .Furthermore, to attract students' attention, all materials are presented in a very attractive form and also attractive topic, because the selection of the material should be based on attractive topics too.

In relation to the design of material or the presentation of material, good and clear instruction are also provided to guide students to work through the reading materials. As a basic consideration so that this product match with the curriculum, the production of this product also considered the competency standard so that it matches with the curriculum. Moreover the presentation of the materials is also typed neatly and has sub headings. The sub headings are bolded and given different color. Consistent with the font point, space and text, assignment, exercises and feedback, in every unit is presented by using appropriate picture, bold or italic text. One more important thing to attract the first sight to this product, a beautiful cover was designed and all the arrangements of the activities including all contents were arranged well. All of what have been mentioned before especially designing color; shape and etc. were conducted to attract students feeling in reading. In a nutshell, by fulfilling all requirement of a good product from Tomlinson (1998) which have been summed up before, the product of this study can be considered as a good product of reading materials.

\section{CONCLUSION}

This study appertained to developing educational product which was reading materials for reading activity at the second year of Islamic education at IAIH NW Anjani. The final product of the development was a book entitled "Let's Read" for reading activity. It contains various simple text-types, relevant illustrations, exercises, and key answers of the exercise for independent study.

At the need assessment step, the lecturer found out that most of the students in $B$ class of the second semester of the students of Islamic education faced difficulty in 
vocabulary items. That such difficulty was worsened by the texts which were too lengthy and some uninteresting topics laid in the commonly published course book. In addition, the English lecturer who was the interviewee also stated that most of her students had problem with vocabulary. However, it can be overcome as long as the materials provided were able to bring attraction and curiosity to them.

After administering need assessment and followed by materials development, the materials were validated by the first expert (E1) and the second expert (E2). Both of E1 and E2 generally stated that the product is worth using. It was because most of the texts included are able to expand students' knowledge as well as the activities provided are not quite burdensome. The teacher, moreover, stated that it was great to motivate the students to learn English through extensive reading activity by providing such product. Most importantly, she further asserted that the language used is below the students' level of difficulty since they have to read it independently.

At the try-out of the product phase, most of the students came to their comfortzone whilst reading. Most of the students were fascinated and felt curious about the text. Once, a student mentioned that he had already been attracted only by reading the title of the text. Another student also commented that the texts were fun and interesting so that at the moment of reading, she did it seriously at the same time felt comfortable. Additionally, this product promotes edutainment activities. It means that any contents of this product focus on educating students as well as entertaining them.

\section{REFRENCES}

Anonymous.2012.Tips of selecting effective authentic reading materials.http://eltresourceful.com. Accessed on January 7 2013

Brown, H.D.2007. Teaching by principle: An Interactive Approach to Language Pedagogy. Third Edition. New York. Pearson Edition
Bamford. 1998. Extensive Reading in The Second Language Classroom. Cambridge: Cambridge University Press

Cunningsworth, A. 1995. Coursebook. London: Macmillan Heinemann (English Language Teaching)

Grabe William and Fredericka L. Stoller. (2002).Teaching and Researching Reading. London: Pearson Education Longman.

Guo.S. 2012. Using Authentic Materials for Extensive Reading to Promote English Proficiency. English Language Teaching; Vol.5, No.8;2012 Canadian Center of Science and Education

Harmer, J.2007. The Practice of English Language Teaching. London. Longman

Ka-Ming Yuen.2011. THE Representation of Foreign Cultures in English Textbook. ELT Journal Volume 65/4 October 2011; Published by Oxford University Press.

Krashen.S.2003.Exploration in Language Acquisition and Use. Portsmouth Heinemann

Krashen.S.2004.Free Voluntary Reading: New Research, Applications, and Controversies. Paper presented at the RELC Conference, Singapore april 2004, retrieved from www.sd. Krashen.com/articles/Singapore.

Kelly, C. 2002.Effective Ways to Use Authentic Matrials with ESL/EFL student. The internet TESOL journal, Vol.VIII, No 11, November 2002. Retrieved from http:/iteslj.org

Latief.A.2009. Educational Research \& Development. On line Publication. University of pittsburg and state university of Malang. Accessed on January 2014.

Lynch, L.2012. Throw Away The Course Book and Adapt Authentic Material.retrieved at February 26, 2013 from

http://www.eslbase.com/article/authenti c-materials-2

Martinez, A.G. 2002. Authentic Materials: an Overview,Karen's Linguistics Issues, 
Terakreditasi Peringkat 5 (No. SK: 85/M/KPT/2020)

retrieved February 26, 2013 from http://www3.telus.net/linguistics issues/authentic-materials.html

Nation, P. 2002.Managing Vocabulary Learning.RELC porto folio series. Orange grove read: SEAMAO Regional Language Center

Nunan, D. 1991. Designing Tasks for Communicative Classroom. Sydney: Cambridge University Press

Ono, L and R, R day and K harsh.2004. Tips for Reading Extensively. English Teaching Forum. October 2004.

Ribahan.2008. Developing Reading Comprehension Materials for Students of Economic Department State Institutes of Islamic studies Mataram. State University of Malang. Unpublished thesis

Richards, J. (2001). Curriculum development in language education. Cambridge: Cambridge University Press

Richard,J.C., \& Roger, T.S. 2001 approaches and method in language teaching.Cambridge: cambridge universty press.

Rohmah, Z. 2009.EFL Materials in Madrasah Tsanawiyah: what do they really need. TEFLIN journal, 20 (1) 104-117.

Rohmah, Z. 2012. Incorporating Islamic Message in The English Teaching in the Indonesia Context,International journal. Social scince \&education 012 vol. 2 issues 2.

Tomlinson, Brian. 1998. MaterialsDevelopment in LanguageTeaching. U.K: Cambridge University Press.

Yalden, J.1985.The Communicative Syllabus Evolution, Design and Implementation. Emford: NY. Pengamon Press 